\title{
Current progress and future perspectives in the development of anti-polo-like kinase 1 therapeutic agents [version 1; peer
}

\section{review: 4 approved]}

\author{
Jung-Eun Park1, David Hymel2, Terrence R. Burke, Jr. 2, Kyung S. Lee(iD1 \\ ${ }^{1}$ Laboratory of Metabolism, Center for Cancer Research, National Cancer Institute, National Institutes of Health, Bethesda, MD, \\ 20892, USA \\ ${ }^{2}$ Chemical Biology Laboratory, Center for Cancer Research, National Cancer Institute at Frederick, Frederick, MD, 21702, USA
}

V1 First published: 29 Jun 2017, 6(F1000 Faculty Rev):1024
https://doi.org/10.12688/f1000research.11398.1

Latest published: 29 Jun 2017, 6(F1000 Faculty Rev):1024

https://doi.org/10.12688/f1000research.11398.1

\section{Abstract}

Although significant levels of side effects are often associated with their use, microtubule-directed agents that primarily target fastgrowing mitotic cells have been considered to be some of the most effective anti-cancer therapeutics. With the hope of developing newgeneration anti-mitotic agents with reduced side effects and enhanced tumor specificity, researchers have targeted various proteins whose functions are critically required for mitotic progression. As one of the highly attractive mitotic targets, polo-like kinase 1 (Plk1) has been the subject of an extensive effort for anticancer drug discovery. To date, a variety of anti-Plk1 agents have been developed, and several of them are presently in clinical trials. Here, we will discuss the current status of generating anti-Plk1 agents as well as future strategies for designing and developing more efficacious antiPlk1 therapeutics.

Keywords anti-cancer therapeutics, anti-mitotic agents, mitotic targets, polo-like kinase 1, Plk1, anti-Plk1 agents

\section{Open Peer Review}

Approval Status

1

2

3

4

version 1

29 Jun 2017

Faculty Reviews are review articles written by the prestigious Members of Faculty Opinions. The articles are commissioned and peer reviewed before publication to ensure that the final, published version is comprehensive and accessible. The reviewers who approved the final version are listed with their names and affiliations.

1. Xiaoqi Liu, Department of Biochemistry, Purdue University, West Lafayette, USA

2. Taebo Sim, Chemical Kinomics Research Center, Korea Institute of Science and Technology, Seoul, South Korea

3. Vincent Archambault, Université de Montréal, Montréal, Canada

4. Wei Dai, New York University School of Medicine, New York, USA

Any comments on the article can be found at the 
end of the article.

Corresponding authors: Terrence R. Burke, Jr. (burkete@helix.nih.gov), Kyung S. Lee (kyunglee@mail.nih.gov)

Competing interests: The authors declare that they have no competing interests.

Grant information: This work was supported in part by the Intramural Research Program of the National Institutes of Health (NIH)

National Cancer Institute (NCI) (K.S.L. and T.R.B).

The funders had no role in study design, data collection and analysis, decision to publish, or preparation of the manuscript.

Copyright: @ 2017 Park JE et al. This is an open access article distributed under the terms of the Creative Commons Attribution License, which permits unrestricted use, distribution, and reproduction in any medium, provided the original work is properly cited. The author(s) is/are employees of the US Government and therefore domestic copyright protection in USA does not apply to this work. The work may be protected under the copyright laws of other jurisdictions when used in those jurisdictions.

How to cite this article: Park JE, Hymel D, Burke, Jr. TR and Lee KS. Current progress and future perspectives in the development of anti-polo-like kinase 1 therapeutic agents [version 1; peer review: 4 approved] F1000Research 2017, 6(F1000 Faculty Rev):1024 https://doi.org/10.12688/f1000research.11398.1

First published: 29 Jun 2017, 6(F1000 Faculty Rev):1024 https://doi.org/10.12688/f1000research.11398.1 


\section{Introduction}

For several decades, anti-microtubule (MT) drugs such as taxanes and vinca alkaloids have been effectively used against a wide range of cancers, including solid and hematological malignancies ${ }^{1}$. However, one of the major shortcomings of these MT-targeting agents has been severe and dose-limiting side effects that arise as the consequence of indiscriminately disrupting widespread MT functions, not only in actively dividing mitotic cells but also in non-dividing interphase cells. Thus, over the past decade, a high level of interest has been drawn to targeting a variety of mitosisspecific proteins in order to develop agents that can specifically disrupt the mitotic progression of highly proliferative cancer cells. These proteins include protein kinases (polo-like kinase 1 $[\mathrm{Plk} 1]^{2}$ and Aurora $\mathrm{A}^{3}$ ), motor proteins $\left(\mathrm{CENP}-\mathrm{E}^{4,5}\right.$ and $\mathrm{Eg} 5^{6}$ ), DNA-damage checkpoint proteins (Chk1 and $\mathrm{Chk}^{7}$ ), and components of the ubiquitin proteasome pathway (APC/Cdc20 and the proteasome $\left.{ }^{8,9}\right)$. Among these endeavors, anti-Plk1 drug discovery has reached an advanced stage of development that merits reflection on its progress. In this short review, we will summarize recent advances and future directions toward developing therapeutics against one of the most appealing anti-cancer drug targets, Plk1.

\section{PIk1 as an anti-mitotic target}

Plk1 belongs to the polo subfamily of Ser/Thr protein kinases (collectively, Plks) and plays a key role at multiple stages of mitotic progression ${ }^{10}$. Plk1 is composed of the $N$-terminal catalytic domain and the $C$-terminal non-catalytic polo-box domain (PBD) (Figure 1). The cooperative action of these two domains is critical for Plk1 to regulate diverse mitotic processes ${ }^{11}$. Not surprisingly, Plk1 is overexpressed in a wide spectrum of human cancers $^{12}$, and its overexpression is thought to promote genomic instability and tumorigenesis ${ }^{13-15}$. In addition, upregulated Plk1 activity appears to be closely associated with the aggressiveness and poor prognosis of these cancers ${ }^{16,17}$. Other studies have shown that various cancer cells-but not their isogenic normal cells-are addicted to Plk1 overexpression for their viability ${ }^{18-20}$. Since reversing addicted protein functions has proven to be an attractive strategy to selectively kill cancer cells ${ }^{18,21-23}$, addiction to overexpressed Plk1 exacerbates the vulnerability of cancer cells to Plk1 interrogation. Thus, targeting Plk1 may permit the induction of cancer-cell-selective mitotic block and apoptotic cell death in Plk1addicted cancers ${ }^{24}$. Because human cancers are frequently slow growing, inhibiting a cancer-addicted target, such as Plk1, could be particularly effective in achieving the full therapeutic potential of an anti-mitotic agent.

\section{Promising PIk1 ATP-competitive inhibitors and their limitations}

Targeting the catalytic activity of a protein kinase has been the predominant method of generating kinase inhibitors. Accordingly, a large number of ATP-competitive inhibitors directed against the catalytic activity of Plk1 have been developed and tested under various preclinical and clinical settings ${ }^{24}$ (Figure 2). Among them, volasertib (a dihydropteridinone derivative; Boehringer Ingelheim) is widely considered the most advanced inhibitor in this class, exhibiting potent anti-tumor activities in multiple nude mouse xenograft models ${ }^{25}$. Volasertib has also shown significant clinical efficacies against advanced solid and hematological cancers in phase I/II clinical trials ${ }^{26-30}$. However, the initial outcome of its phase III clinical trials, performed with a cohort of elderly acute myeloid leukemia patients, turned out to be less

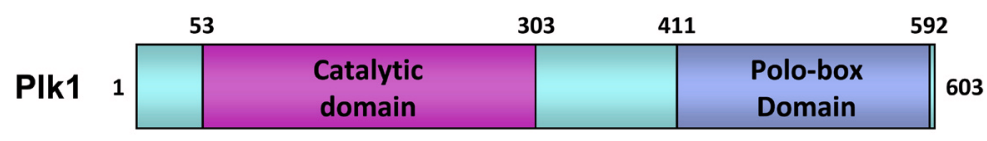

Figure 1. Schematic diagram of human polo-like kinase 1 (Plk1). The numbers indicate the positions of the amino acid residues in human Plk1.

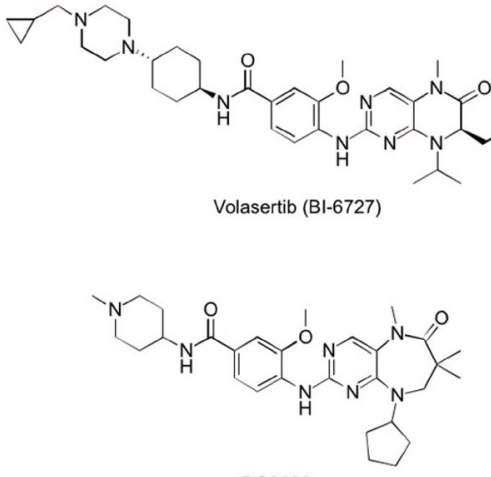

$\mathrm{RO} 3280$
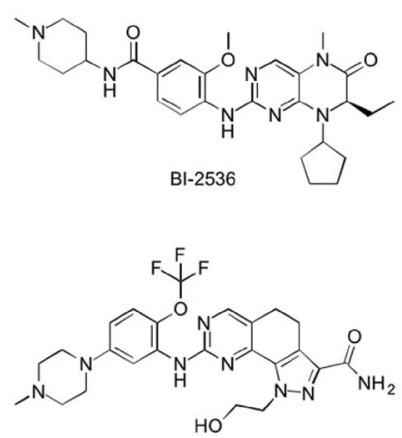

NMS-P937
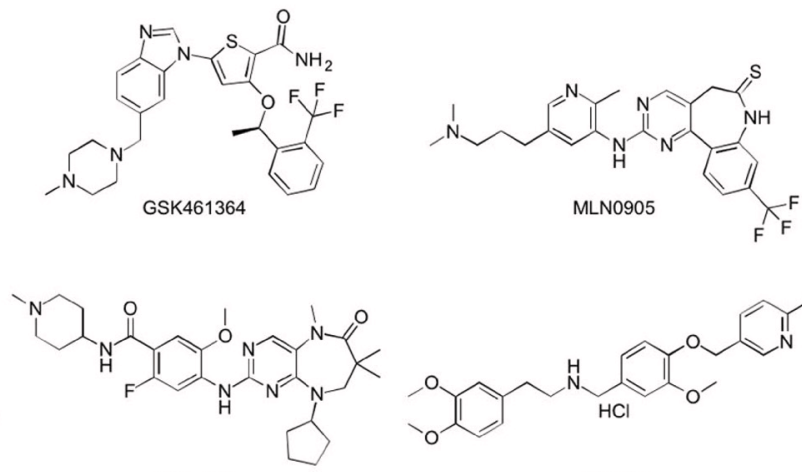

TAK-960

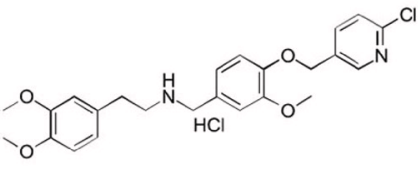

SBE13

Figure 2. The structures of polo-like kinase 1 (PIk1) catalytic domain inhibitors. Only widely studied inhibitors are shown. 
than satisfactory (the 21st Annual Congress of the European Hematology Association, 2016). In addition, several other ATP-competitive inhibitors, such as GSK461364 (a thiophene derivative; GlaxoSmithKline) ${ }^{31}$, MLN0905 (a benzolactam derivative; Millennium) ${ }^{32,33}$, RO3280 (a pyrimidodiazepine derivative; Roche $)^{34,35}$, NMS-P937 (a pyrazoloquinazoline derivative;

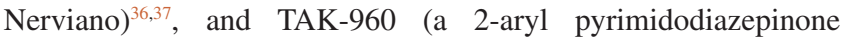
derivative; Takeda) ${ }^{38}$ have shown only limited efficacy with morethan-acceptable dose-limiting toxicity in diverse preclinical/ clinical trials. Dose-limiting toxicity arises mainly from nonspecific activity of the inhibitors ${ }^{39}$. In fact, one of the common problems associated with the currently available Plk1 ATPcompetitive inhibitors is their low degree of selectivity against other kinases ${ }^{24}$, including two that are closely related, Plk2 and Plk3, with possible tumor-suppressor function ${ }^{40,41}$. Therefore, improving Plk1 specificity is likely one of the most pressing concerns to address in order to accomplish better clinical outcomes with fewer toxicological problems.

\section{Future strategies to conquer current obstacles}

Generating ATP-competitive inhibitors aimed at inhibiting the catalytic activity of a protein kinase is a widely used approach, in part, because isolating small molecules that block the catalytic activity of a kinase is relatively straightforward. However, owing to the highly conserved nature of the ATP-binding pocket, a large fraction of this class of inhibitors show a significant level of cross-reactivity with various other kinases ${ }^{39}$. Therefore, for a given kinase, having a better understanding of the exact nature of the ATP-binding site (and its neighboring interaction pockets, if they exist) could be crucial for overcoming lack of specificity associated with non-allosteric ATP-competitive inhibitors.

Improving specificity through structure-assisted optimization Further development of Plk1 ATP-competitive inhibitors can be achieved through structure-guided medicinal chemistry targeting unique residues lining the ATP-binding pocket. Comparative analyses of the X-ray co-crystal structures of the catalytic domains of Plk1-3 revealed that the overall shapes of their ATP-binding pockets are similar, and the residues forming the pockets are mostly analogous to one another. Nevertheless, both F58 and R134 residues are unique to Plk1, whereas R57, L132, and R136 residues found in Plk1 and one of Plk2 and Plk3 ATP-binding pockets are semispecific to $\mathrm{Plk}^{24}$ (Figure 3 ). These observations suggest that there may still be explorable chemical space, which can be exploited to further increase Plk1-binding specificity. Notably, volasertib and its parental dihydropteridinone derivative, BI $2536^{42}$, do not interact with the Plk1-specific F58 and R134 residues but are in contact with the semi-specific R57, L132, and R136 residues and other neighboring residues $(\mathrm{C} 67, \mathrm{~L} 132$, and $\mathrm{F} 183)$ that are somewhat selective against non-Plks (Figure 3). This finding explains in part why they exhibit a high level ( 100-1,000-fold) of selectivity against other kinases but show less discriminatory activity against Plk1-3 $\left(\mathrm{IC}_{50}\right.$ values of $0.83,5$, and $56 \mathrm{nM}$ for Plk1, Plk2, and Plk3, respectively) ${ }^{25,43}$.

As noted above, one of the few differences between the ATP-binding pockets of Plk1 and Plk2 occurs near the hinge region (region II in Figure 3), where L132 of Plk1 corresponds to Y161 in Plk2. This difference has been exploited to generate inhibitors that demonstrate $\sim 1,000$-fold selectivity for Plk2 versus Plk1 ${ }^{44}$. Such work highlights what can be achieved using structure-based drug design to take advantage of small differences in protein-binding sites. An additional effort to target the Plk1-specific F58 and R134 residues that lie at the mouth of the core ATP-binding pocket (Figure 3 ) could lead to inhibitors with improved selectivity against other Plks. The generation of isoform-selective inhibitors is critically important to elucidate the biological roles of each individual Plk isoform, along with determining the importance of isoform selectivity in preventing the currently observed dose-limiting toxicities. Insights derived from such studies could further reveal the potential therapeutic value of targeting the catalytic domain of Plk1.
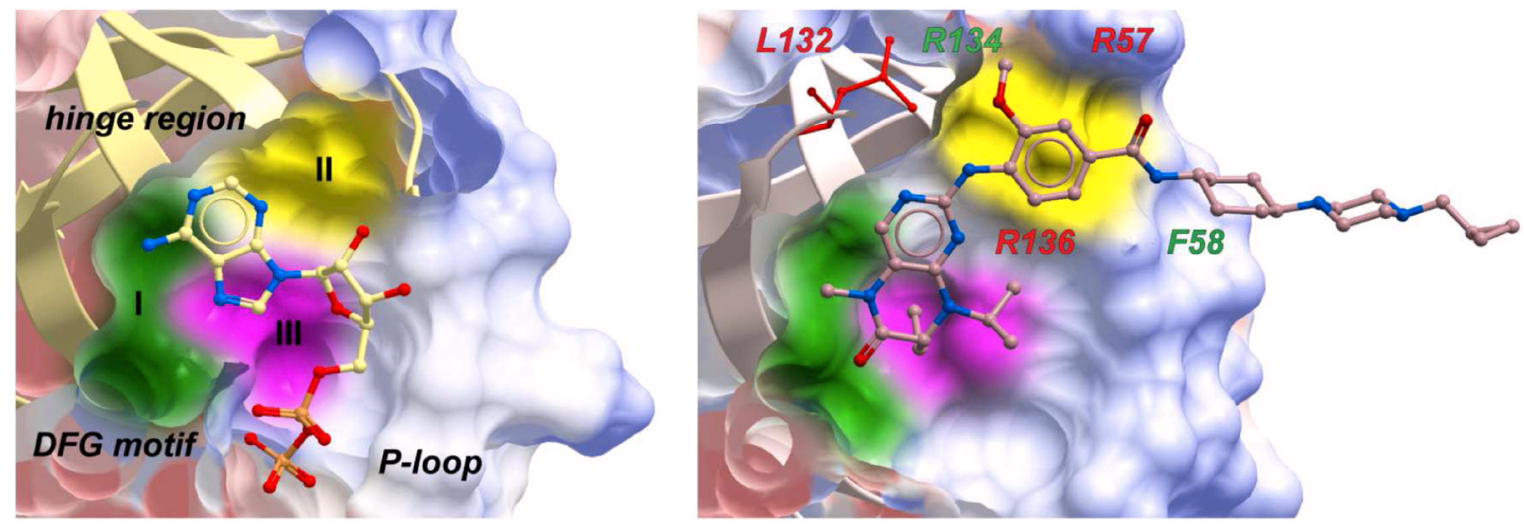

Figure 3. The binding modes of ADP (left panel, PDB: 3D5W) and volasertib (right panel, PDB: 3FC2) to the catalytic domain of pololike kinase 1 (PIk1). Ligand-binding regions that are important for achieving kinase selectivity are shown as colored surfaces. Region I is located near the conserved Asp-Phe-Gly (DFG) motif, which is important in the design of certain allosteric inhibitors. Region II is near the hinge region, and region III is a relatively hydrophobic pocket below the adenine-binding site. Compared to Plk2 and Plk3, residues that are specific (green) or semi-specific (red) to Plk1 are labeled. Notably, the aryl-methoxy group in region II (near L132 of the hinge region) is used to produce moderate selectivity for Plk1 against other Plks ${ }^{44}$. 


\section{Developing allosteric inhibitors}

To ensure high selectivity, ATP-competitive small molecules must be designed to maximally engage in receptor-ligand interactions or sterically fill unoccupied space within defined binding pockets. In addition, because allosteric sites are generally less conserved than orthosteric sites, developing strategies to target allosteric sites, if available, can be potentially very useful in deriving specific inhibitors against a target. Close examination of the co-crystal structures of the Plk1 catalytic domain in complex with either ADP or volasertib reveals three ligand-binding regions (regions I, II, and III) that are important for achieving kinase selectivity (Figure 3). Volasertib appears to utilize each of these orthosteric binding regions to achieve selectivity against most clinically important kinases. It is noteworthy that the region I located near the conserved Asp-Phe-Gly (DFG) motif contains a shallow space that could be potentially utilized to further improve the drug-target interaction. Interestingly, a dimethoxybenzeneethanamine derivative, SBE13, is suggested to bind to Plk1 in its "DFG-out" conformation and inhibit the enzyme's catalytic activity with outstanding specificity ${ }^{45,46}$. An allosteric hydrophobic pocket generated in the catalytically inactive, DFG-out conformation of many Tyr kinases and, less frequently, Ser/Thr kinases has been successfully targeted to improve the selectivity of an inhibitor ${ }^{47-49}$. However, no structural information is yet available to verify whether Plk1 can indeed embrace a DFG-out conformation and generate an allosteric hydrophobic pocket that potentially allows an ATP-competitive inhibitor to trap the enzyme in a catalytically inactive state.

Another potentially appealing strategy toward achieving targetspecific allosteric inhibition of Plk1 could be to block its essential substrate-binding interface. In principle, this may be approached by understanding the nature of the Plk1-substrate binding interactions that are critical for proper mitotic progression. ON01910, a substituted benzyl styryl sulfone, was initially reported as a nonATP-competitive inhibitor of Plk1 that was thought to interfere with the substrate-binding site ${ }^{50}$. However, subsequent studies showed that it possesses rather poor anti-Plk1 activity and specificity and inhibits multiple kinases ${ }^{43,51-53}$. In a broad sense, the anti-PBD agents described below can be classified as target-specific allosteric inhibitors, which inhibit Plk1 function by binding to a specific site distant from the ATP-binding pocket.

\section{The PBD as an alternative target for anti-PIk1 drug discovery}

The PBD is a functionally essential domain that binds to the enzyme's physiological substrates and mediates the cis-acting phosphorylation of bound substrates by the $\mathrm{N}$-terminal catalytic domain $^{54}$. A large body of evidence suggests that the Plk1 PBD contains a well-defined protein-protein interaction (PPI) pocket that can be inhibited by short peptides or peptide mimetics ${ }^{24}$. Intriguingly, inhibition of Plk1 PBD function alone is sufficient for effectively imposing mitotic arrest and apoptotic cell death in cancer cells but not in normal cells ${ }^{20}$. This suggests that targeting the PBD may serve as a promising alternative for developing anti-Plk1 therapeutics. It should be noted, however, that not all of Plk1's substrates require a prior interaction with the PBD before being phosphorylated by its $N$-terminal catalytic domain ${ }^{54}$. Therefore, inhibiting
PBD function represents a target-restricted strategy that is designed to antagonize a subset of Plk1 functions dysregulated in cancer ${ }^{24,54}$.

\section{Advantages of targeting the PIk1 PBD}

Unlike ATP-competitive inhibitors, whose specificities must be obtained against more than 500 other cellular kinases ${ }^{39}$, PBD inhibitors target a structurally unique domain found in only four proteins (Plk1-3 and Plk5) ${ }^{24}$. This greatly diminishes the likelihood of facing unwanted non-specific cross-reactivities. Another potential advantage of targeting the PBD is that while ATP-competitive inhibitors can abrogate all Plk1-dependent biochemical processes indiscriminately in both cancer and normal cells, PBD inhibitors interfere in only a subset of Plk1 functions that require a PBDmediated biochemical step. Furthermore, since the Plk1 PBD can interact with a variety of structurally diverse phosphoepitopecontaining proteins $\mathrm{s}^{54}$, it is reasonable to speculate that anti-PBD agents could potentially be optimized so that they selectively inhibit a subset of PBD-dependent interactions, which are enriched in biochemically rewired, Plk1-addicted cancer cells ${ }^{24}$.

\section{Current status on the development of anti-PIk1 PBD agents}

Peptidomimetics

Since the initial discovery of a pentameric p-Thr-containing peptide, PLHSpT, as a specific Plk1 PBD-binding ligand ${ }^{55}$, several high-affinity peptide-derived inhibitors, including $4 \mathrm{j}$ (Figure 4), have been generated ${ }^{56-58}$. These efforts have revealed that three distinct structural elements are critical for achieving high affinity and specific binding to the Plk1 PBD (Figure 5). These are 1) a phosphoepitope-recognition pocket containing two basic residues (His538 and Lys540), which binds to Ser-Xxx motifs, where Xxx is $\mathrm{p}$-Thr (or several-fold lower-affinity $\mathrm{p}$-Ser) or a suitable anionic mimetic $\left.{ }^{55,59}, 2\right)$ an adjoining Pro-binding region that engages portions of the bound ligand $N$-proximal to the Ser-p-Thr dipeptide motif $^{55}$, and 3) a hydrophobic channel, which is capable of boosting the binding affinity 500-1,000-fold without compromising Plk1 PBD specificity ${ }^{56-59}$. However, despite the fact that these peptidebased inhibitors exhibit extremely high affinity and specificity in vitro, their utility in cellular contexts is greatly decreased by poor membrane permeability and limited bioavailability. Efforts to increase cellular uptake have been directed at the reduction of anionic charge through charge masking and prodrug protection ${ }^{60}$, macrocyclization $^{61,62}$, and reducing peptide character ${ }^{63}$.

\section{Small molecule inhibitors}

Paralleling the development of peptidomimetics as described above are efforts to generate anti-Plk1 PBD agents that have yielded a wide range of small molecule inhibitors, including thymoquinone (TQ) and poloxin ${ }^{64}$, poloxipan ${ }^{65}$, purpurogallin (PPG) ${ }^{66}, \mathrm{~T}^{2} 21^{67}$, Cpd161 $^{68}$, and (-)-epigallocatechin ${ }^{69}$ (Figure 4). As expected, if they interfered with the function of Plk1 PBD, these inhibitors induce mitotic block and apoptotic cell death, at least at the cultured cell level. While X-ray crystallographic data suggested the binding nature of how TQ and its analogue poloxime bound to the p-Thr/p-Ser-binding module ${ }^{70}$, the assignment of these ligands within the phosphoepitope-recognition module appears to be disputable because of the poor resolution of the reported crystal structures. In addition, whether TQ and poloxin can be used as a 
<smiles>CC(=O)N1CCCC1C(=O)NC(CC(C)C)C(=O)NC(Cc1nncn1Cc1ccccc1)C(=O)NC(CO)C(=O)NC(CC(C)(C)O)C(N)=O</smiles>

4j, $X=O$

$4 j^{*}, X=\mathrm{CH}_{2}$<smiles></smiles>

Purpurogallin

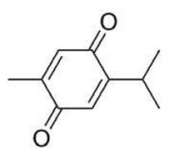

Thymoquinone<smiles></smiles>

Poloxin<smiles>C=CS(=O)(=O)c1cc(C)cc(C(F)(F)F)c1</smiles>

Cpd161<smiles>COc1ccc(Br)cc1/C=c1\sc2nc(=O)c(C)nn2c1=O</smiles>

Poloxipan<smiles>Oc1cc(O)c2c(c1)OC(c1cc(O)c(O)c(O)c1)C(O)C2</smiles>

(-)-epigallocatechin

Figure 4. The structures of peptidomimetic and small molecule polo-box domain (PBD) inhibitors.

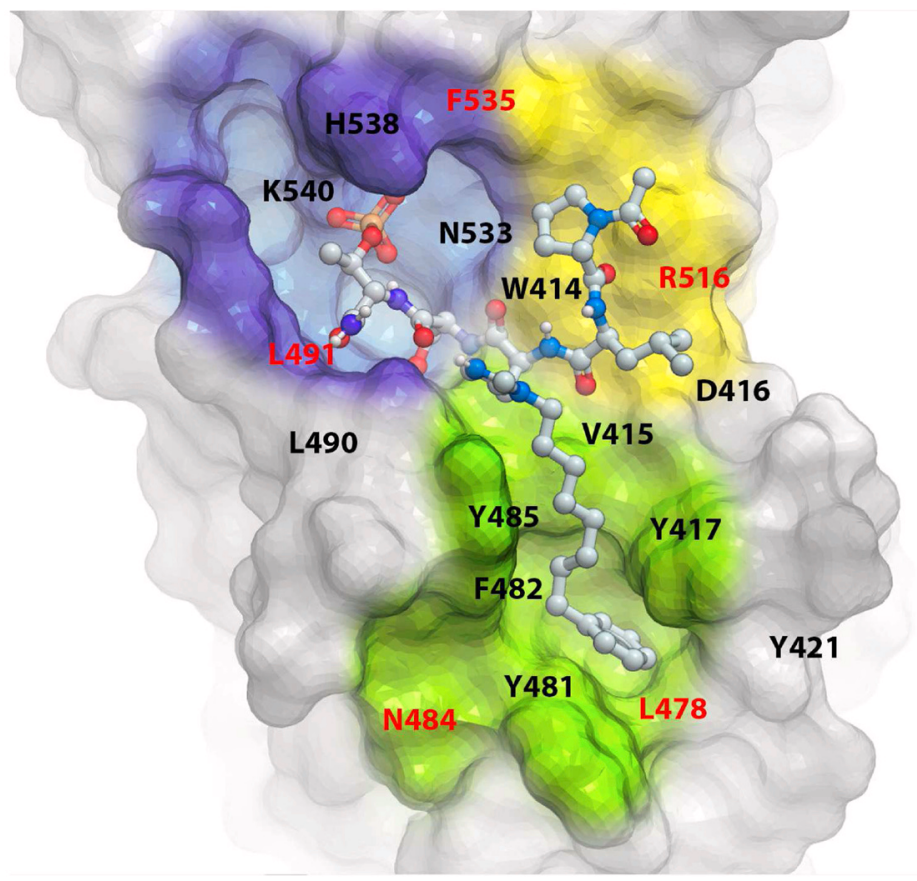

Figure 5. The structural model of polo-box domain (PBD) in complex with $\mathbf{4 j}$. The $X$-ray cocrystal structure of the PBD $+4 \mathrm{j}$ complex (PDB: 3RQ7) shows a "Y-shaped" binding pocket composed of three discrete but interlinked binding modules-namely, a p-Thr/p-Ser-binding module (violet), a Pro-binding module (yellow), and a hydrophobic channel (green). Residues highlighted in red are specific to PIk1 PBD. Inhibitors designed to bind to more than one of the three binding modules could possess a superior binding specificity because of the specific requirement of the shape and geometrical arrangement of their binding moieties (see text for details).

template for structure-assisted drug design and hit-to-lead optimization remains in doubt because of their low Plk1 PBD specificity and non-specific alkylating activity with other cellular proteins ${ }^{68,71,72}$. Indeed, covalent protein reactivity and other chemotypes, such as polyhydroxylated aromatic compounds (e.g. PPG), are thought to be some of the common artifacts that lead to the isolation of pan assay interference compounds (PAINS) ${ }^{73}$ (as discussed in depth in a recent review ${ }^{74}$ ). 
Future directions in anti-PIk1 PBD drug discovery

Multidirectional approaches to identify a lead with druggable properties

Even though currently available peptide-derived and small molecule inhibitors have provided valuable information in understanding the nature of Plk1 PBD-dependent interactions and their cellular functions, it remains uncertain whether they can be used as leads for developing anti-PBD agents. Therefore, while these inhibitors are being further developed, additional endeavors could be considered in parallel in the hope of generating a new class of inhibitors with more druggable properties. Identifying promising leads possessing outstanding biochemical selectivity (i.e. specificity and affinity) and druggable physicochemical properties (e.g. solubility, bioavailability, chemical functionality, etc.) will likely be a critical step for successful lead optimization and ultimate discovery of anti-Plk1 PBD therapeutic agents.

Exploiting the shape and geometrical arrangement of three adjacent binding modules of the PIk1 PBD-binding pocket to achieve high specificity

Now it is clear that, unlike the nondescript nature of many PPI surfaces, the Plk1 PBD furnishes a well-defined binding interface that may make it more amenable for structure-based drug discovery. Accumulated data show that the affinity and specificity of Plk1 PBD binding are dependent on the ability of a ligand to interact with three adjacently placed but biochemically distinct binding modules ${ }^{55,56}$ that collectively form a "Y-shaped" binding pocket (reviewed in Lee et al. $^{24}$ ) (Figure 5). Future anti-Plk1 PBD drug discovery could take advantage of the Y-shaped interaction interface, so that ligands are optimized as three discrete but interconnected binding-module platforms.

Recent work has demonstrated that suitably designed $\mathrm{p}$-Thr mimetic derivatives optimized for the phosphoepitope-recognition module can achieve several-fold enhancement in PBD-binding affinity $^{75}$. In addition, structural elaboration of hydrophobic channel-binding functionality and improvement of the interactions with Plk1-specific residues found in the surroundings of the hydrophobic channel have significantly increased overall ligand affinity and selectivity ${ }^{76,77}$. These findings suggest that the binding affinity and specificity of each of the three binding modules are determined independently of one another. Since a ligand capable of simultaneously binding to two or more binding modules must additionally conform to the exact geometrical arrangement of these modules, anti-Plk1 PBD agents generated through the Y-shaped, threebinding-module platform (Figure 5) may likely possess uncommon physical shapes and chemical properties that may allow them to reach a high level of specificity. Multiple modular bindings discussed here may also help diminish the probability of developing drug resistance.

\section{Concluding remarks}

Given the significant level of side effects associated with conventional MT-targeting anticancer therapeutics, developing an inhibitor against a mitosis-specific and cancer-cell-addicted target such as Plk1 may represent a promising strategy for the generation of a cancer-cell-specific therapeutic agent. One of the unique molecular features of Plk1 is that it offers, within one molecule, two independent drug targets- the $N$-terminal catalytic domain and the $C$-terminal PBD. The primary challenge facing currently available ATP-competitive inhibitors of Plk1 appears to be their doselimiting toxicities. Although this hurdle can be conquered in principle by improving specificity or generating potentially more specific allosteric inhibitors as discussed above, considering extensive efforts made to date, this advancement may not be easily accomplished unless a breakthrough occurs. In this regard, it is quite intriguing to define the PBD as an alternative target for anti-Plk1 drug discovery. In addition to the superb binding specificity that PPI inhibitors can bring, Plk1 PBD inhibitors can provide an opportunity to selectively interfere with cancer-cell-enriched Plk1 PBD-binding targets. If developed, Plk1 PBD inhibitors with superior specificity can be used not only as a single therapeutic agent but also as an agent easily amenable for combination therapy with other anti-cancer therapeutics.

Significantly, the use of multiple inhibitors targeting different regions within one molecule is considered an effective way to eliminate drug resistance and to diminish the side effects of a high dose of a single agent. Therefore, using a Plk1 PBD inhibitor in combination with an ATP-competitive inhibitor, such as volasertib, could present a great treatment regimen that may achieve the maximum drug efficacy of both inhibitors while keeping volasertib at the highest acceptable dose that does not cause nonspecific cytotoxicity. Considering the success of anti-mitotic therapeutics and the remarkable advantages of targeting Plk1, there is ample reason to believe that further developing anti-Plk1 therapeutics may prove to be a worthwhile endeavor in the fight against cancer.

\section{Author contributions}

K.S.L., T.R.B., J.E.P., and D.H. wrote the manuscript, and T.R.B., J.E.P., and D.H. generated figures.

\section{Competing interests}

The authors declare that they have no competing interests.

\section{Grant information}

This work was supported in part by the Intramural Research Program of the National Institutes of Health (NIH) National Cancer Institute (NCI) (K.S.L. and T.R.B).

The funders had no role in study design, data collection and analysis, decision to publish, or preparation of the manuscript.

\section{Acknowledgements}

We are grateful to our past and present colleagues for stimulating discussions and sharing insights. We apologize to all authors whose work could not be cited owing to space limitations. 
1. Dumontet $C$, Jordan MA: Microtubule-binding agents: a dynamic field of cancer therapeutics. Nat Rev Drug Discov. 2010; 9(10): 790-803. PubMed Abstract | Publisher Full Text | Free Full Text

2. Strebhardt K: Multifaceted polo-like kinases: drug targets and antitargets for cancer therapy. Nat Rev Drug Discov. 2010; 9(8): 643-60. PubMed Abstract | Publisher Full Text

3. Keen N, Taylor S: Aurora-kinase inhibitors as anticancer agents. Nat Rev Cancer. 2004; 4(12): 927-36.

PubMed Abstract | Publisher Full Text

4. Wood KW, Sakowicz R, Goldstein LS, et al: CENP-E is a plus end-directed kinetochore motor required for metaphase chromosome alignment. Cell. 1997; 91(3): 357-66.

PubMed Abstract | Publisher Full Text

5. Yen TJ, Li G, Schaar BT, et al:: CENP-E is a putative kinetochore motor that accumulates just before mitosis. Nature. 1992; 359(6395): 536-9. PubMed Abstract | Publisher Full Text

6. Blangy $\mathrm{A}$, Lane $\mathrm{HA}$, d'Herin $\mathrm{P}$, et al:: Phosphorylation by $\mathrm{p} 34^{\mathrm{cdc2}}$ regulates spindle association of human Eg5, a kinesin-related motor essential for bipolar spindle formation in vivo. Cell. 1995; 83(7): 1159-69. PubMed Abstract | Publisher Full Text

7. F Matt S, Hofmann TG: The DNA damage-induced cell death response: roadmap to kill cancer cells. Cell Mol Life Sci. 2016; 73(15): 2829-50. PubMed Abstract | Publisher Full Text | F1000 Recommendation

8. F Sivakumar S, Gorbsky GJ: Spatiotemporal regulation of the anaphasepromoting complex in mitosis. Nat Rev Mol Cell Biol. 2015; 16(2): 82-94. PubMed Abstract | Publisher Full Text | Free Full Text | F1000 Recommendation

9. F Manasanch EE, Orlowski RZ: Proteasome inhibitors in cancer therapy. Nat Rev Clin Oncol. 2017; 14(7): 417-433.

PubMed Abstract | Publisher Full Text | F1000 Recommendation

10. F Archambault V, Lépine G, Kachaner D: Understanding the Polo Kinase machine. Oncogene. 2015; 34(37): 4799-807.

PubMed Abstract | Publisher Full Text | F1000 Recommendation

11. Park JE, Erikson RL, Lee KS: Feed-forward mechanism of converting biochemical cooperativity to mitotic processes at the kinetochore plate. Proc Natl Acad Sci U S A. 2011; 108(20): 8200-5.

PubMed Abstract | Publisher Full Text | Free Full Text

12. Holtrich $\mathrm{U}$, Wolf $\mathrm{G}$, Bräuninger $\mathrm{A}$, et al:: Induction and down-regulation of PLK, a human serine/threonine kinase expressed in proliferating cells and tumors. Proc Natl Acad Sci U S A. 1994; 91(5): 1736-40.

PubMed Abstract | Publisher Full Text | Free Full Text

13. Eckerdt F, Yuan J, Strebhardt K: Polo-like kinases and oncogenesis. Oncogene. 2005; 24(2): 267-76.

PubMed Abstract | Publisher Full Text

14. Takai N, Hamanaka R, Yoshimatsu J, et al.: Polo-like kinases (Plks) and cancer. Oncogene. 2005; 24(2): 287-91.

PubMed Abstract | Publisher Full Text

15. Cholewa BD, Liu X, Ahmad N: The role of polo-like kinase 1 in carcinogenesis: cause or consequence? Cancer Res. 2013; 73(23): 6848-55. PubMed Abstract | Publisher Full Text | Free Full Text

16. Wolf $\mathrm{G}$, Elez $\mathrm{R}$, Doermer $\mathrm{A}$, et al.: Prognostic significance of polo-like kinase (PLK) expression in non-small cell lung cancer. Oncogene. 1997; 14(5): 543-9. PubMed Abstract | Publisher Full Text

17. Knecht $\mathrm{R}$, Elez $\mathrm{R}$, Oechler $\mathrm{M}$, et al.: Prognostic significance of polo-like kinase (PLK) expression in squamous cell carcinomas of the head and neck. Cancer Res. 1999; 59(12): 2794-7. PubMed Abstract

18. F Luo J, Emanuele MJ, Li D, et al.: A genome-wide RNAi screen identifies multiple synthetic lethal interactions with the Ras oncogene. Cell. 2009; 137(5): 835-48.

PubMed Abstract | Publisher Full Text | Free Full Text | F1000 Recommendation

19. F Sur S, Pagliarini R, Bunz F, et al:: A panel of isogenic human cancer cells suggests a therapeutic approach for cancers with inactivated p53. Proc Nat Acad Sci U S A. 2009; 106(10): 3964-9. PubMed Abstract | Publisher Full Text | Free Full Text | F1000 Recommendation

20. Park JE, Kim TS, Kim BY, et al.: Selective blockade of cancer cell proliferation and anchorage-independent growth by PIk1 activity-dependent suicida inhibition of its polo-box domain. Cell Cycle. 2015; 14(22): 3624-34. PubMed Abstract | Publisher Full Text | Free Full Text

21. Weinstein IB: Cancer. Addiction to oncogenes--the Achilles heal of cancer. Science. 2002; 297(5578): 63-4. PubMed Abstract | Publisher Full Text

22. F McMurray HR, Sampson ER, Compitello G, et al:: Synergistic response to oncogenic mutations defines gene class critical to cancer phenotype. Nature. 2008; 453(7198): 1112-6.

PubMed Abstract | Publisher Full Text | Free Full Text | F1000 Recommendation

23. Luo J, Solimini NL, Elledge SJ: Principles of cancer therapy: oncogene and non-oncogene addiction. Cell. 2009; 136(5): 823-37.

PubMed Abstract | Publisher Full Text | Free Full Text

24. Lee KS, Burke TR Jr, Park JE, et al:: Recent Advances and New Strategies in Targeting Plk1 for Anticancer Therapy. Trends Pharmacol Sci. 2015; 36(12): 858-77.

PubMed Abstract | Publisher Full Text | Free Full Text

25. Rudolph D, Steegmaier M, Hoffmann M, et al.: BI 6727, a Polo-like kinase inhibitor with improved pharmacokinetic profile and broad antitumor activity. Clin Cancer Res. 2009; 15(9): 3094-102.

PubMed Abstract | Publisher Full Text

26. F Awada A, Dumez H, Aftimos PG, et al.: Phase I trial of volasertib, Polo-like kinase inhibitor, plus platinum agents in solid tumors: safety, pharmacokinetics and activity. Invest New Drugs. 2015; 33(3): 611-20. PubMed Abstract | Publisher Full Text | Free Full Text | F1000 Recommendation

27. Schöffski P, Awada A, Dumez H, et al:: A phase I, dose-escalation study of the novel Polo-like kinase inhibitor volasertib (BI 6727) in patients with advanced solid tumours. Eur J Cancer. 2012; 48(2): 179-86.

PubMed Abstract | Publisher Full Text

28. Willemze R, Suciu S, Meloni G, et al:: High-dose cytarabine in induction treatment improves the outcome of adult patients younger than age 46 years with acute myeloid leukemia: results of the EORTC-GIMEMA AML-12 trial. J Clin Oncol. 2014; 32(3): 219-28.

PubMed Abstract | Publisher Full Text

29. Döhner H, Lübbert M, Fiedler W, et al:: Randomized, phase 2 trial of low-dose cytarabine with or without volasertib in AML patients not suitable for induction therapy. Blood. 2014; 124(9): 1426-33.

PubMed Abstract | Publisher Full Text | Free Full Text

30. F Gjertsen BT, Schöffski P: Discovery and development of the Polo-like kinase inhibitor volasertib in cancer therapy. Leukemia. 2015; 29(1): 11-9. PubMed Abstract | Publisher Full Text | Free Full Text | F1000 Recommendation

31. Olmos D, Barker D, Sharma R, et al.: Phase I study of GSK461364, a specific and competitive Polo-like kinase 1 inhibitor, in patients with advanced solid malignancies. Clin Cancer Res. 2011; 17(10): 3420-30.

PubMed Abstract | Publisher Full Text

32. Duffey MO, Vos TJ, Adams R, et al:: Discovery of a potent and orally bioavailable benzolactam-derived inhibitor of Polo-like kinase 1 (MLN0905). J Med Chem. 2012; 55(1): 197-208.

PubMed Abstract | Publisher Full Text

33. Shi JQ, Lasky K, Shinde V, et al:: MLN0905, a small-molecule plk1 inhibitor, induces antitumor responses in human models of diffuse large B-cell lymphoma. Mol Cancer Ther. 2012; 11(9): 2045-53. PubMed Abstract | Publisher Full Text

34. Chen S, Bartkovitz D, Cai J, et al.: Identification of novel, potent and selective inhibitors of Polo-like kinase 1. Bioorg Med Chem Lett. 2012; 22(2): 1247-50. PubMed Abstract | Publisher Full Text

35. F Wang NN, Li ZH, Zhao H, et al:: Molecular targeting of the oncoprotein PLK1 in pediatric acute myeloid leukemia: RO3280, a novel PLK1 inhibitor induces apoptosis in leukemia cells. Int J Mol Sci. 2015; 16(1): 1266-92. PubMed Abstract | Publisher Full Text | Free Full Text | F1000 Recommendation

36. Beria I, Bossi RT, Brasca MG, et al.: NMS-P937, a 4,5-dihydro-1H-pyrazolo[4,3h]quinazoline derivative as potent and selective Polo-like kinase 1 inhibitor. Bioorg Med Chem Lett. 2011; 21(10): 2969-74.

PubMed Abstract | Publisher Full Text

37. Valsasina B, Beria I, Alli C, et al.: NMS-P937, an orally available, specific smallmolecule polo-like kinase 1 inhibitor with antitumor activity in solid and hematologic malignancies. Mol Cancer Ther. 2012; 11(4): 1006-16. PubMed Abstract | Publisher Full Text

38. Hikichi Y, Honda K, Hikami K, et al.: TAK-960, a novel, orally available, selective inhibitor of polo-like kinase 1 , shows broad-spectrum preclinical antitumor activity in multiple dosing regimens. Mol Cancer Ther. 2012; 11(3): 700-9. PubMed Abstract | Publisher Full Text

39. F Karaman MW, Herrgard S, Treiber DK, et al:: A quantitative analysis of kinase inhibitor selectivity. Nat Biotechnol. 2008; 26(1): 127-32. PubMed Abstract | Publisher Full Text | F1000 Recommendation

40. Syed N, Smith P, Sullivan A, et al:: Transcriptional silencing of Polo-like kinase 2 (SNK/PLK2) is a frequent event in B-cell malignancies. Blood. 2006; 107(1): 250-6.

PubMed Abstract | Publisher Full Text

41. Yang $Y$, Bai J, Shen $R$, et al: Polo-like kinase 3 functions as a tumor suppressor and is a negative regulator of hypoxia-inducible factor-1 alpha under hypoxic conditions. Cancer Res. 2008; 68(11): 4077-85. PubMed Abstract | Publisher Full Text | Free Full Text

42. $\mathrm{F}$ Lénárt $\mathrm{P}$, Petronczki M, Steegmaier $\mathrm{M}$, et al.: The small-molecule inhibitor $\mathrm{BI}$ 2536 reveals novel insights into mitotic roles of polo-like kinase 1. Curr Biol. 2007; 17(4): 304-15

PubMed Abstract | Publisher Full Text | F1000 Recommendation

43. Steegmaier M, Hoffmann M, Baum A, et al.: BI 2536, a potent and selective 
inhibitor of polo-like kinase 1, inhibits tumor growth in vivo. Curr Biol. 2007; 17(4): 316-22.

PubMed Abstract | Publisher Full Text

44. Aubele DL, Hom RK, Adler M, et al:: Selective and brain-permeable polo-like kinase-2 (Plk-2) inhibitors that reduce $\alpha$-synuclein phosphorylation in rat brain. ChemMedChem. 2013; 8(8): 1295-313.

PubMed Abstract | Publisher Full Text

45. Keppner S, Proschak E, Schneider G, et al:: Identification and validation of a potent type II inhibitor of inactive polo-like kinase 1. ChemMedChem. 2009; 4(11): 1806-9.

PubMed Abstract | Publisher Full Text

46. Keppner S, Proschak E, Kaufmann M, et al.: Biological impact of freezing Plk1 in its inactive conformation in cancer cells. Cell Cycle. 2010; 9(4): 761-73. PubMed Abstract | Publisher Full Text

47. Liu Y, Gray NS: Rational design of inhibitors that bind to inactive kinase conformations. Nat Chem Biol. 2006; 2(7): 358-64.

PubMed Abstract | Publisher Full Text

48. Yang W, Chen $Y$, Zhou X, et al:: Design, synthesis and biological evaluation of bis-aryl ureas and amides based on 2-amino-3-purinylpyridine scaffold as DFG-out B-Raf kinase inhibitors. Eur J Med Chem. 2015; 89: 581-96. PubMed Abstract | Publisher Full Text

49. Dietrich J, Gokhale V, Wang X, et al.: Application of a novel [3+2] cycloaddition reaction to prepare substituted imidazoles and their use in the design of potent DFG-out allosteric B-Raf inhibitors. Bioorg Med Chem. 2010; 18(1): 292-304.

PubMed Abstract | Publisher Full Text

50. F Gumireddy K, Reddy MV, Cosenza SC, et al:: ON01910, a non-ATPcompetitive small molecule inhibitor of PIk1, is a potent anticancer agent. Cancer Cell. 2005; 7(3): 275-86.

PubMed Abstract | Publisher Full Text | F1000 Recommendation

51. Bowles DW, Diamond JR, Lam ET, et al:: Phase I study of oral rigosertib (ON 01910.Na), a dual inhibitor of the PI3K and PIk1 pathways, in adult patients with advanced solid malignancies. Clin Cancer Res. 2014; 20(6): 1656-65. PubMed Abstract | Publisher Full Text | Free Full Text

52. Reddy MV, Venkatapuram P, Mallireddigari MR, et al.: Discovery of a clinical stage multi-kinase inhibitor sodium (E)-2-\{2-methoxy-5-[(2',4',6'-trimethoxysty rylsulfonyl)methyl]phenylamino\}acetate (ON 01910.Na): synthesis, structureactivity relationship, and biological activity. J Med Chem. 2011; 54(18): 6254-76.

PubMed Abstract | Publisher Full Text | Free Full Text

53. Peters $\mathrm{U}, \mathrm{Cherian} \mathrm{J}, \mathrm{Kim} \mathrm{JH}$, et al: Probing cell-division phenotype space and Polo-like kinase function using small molecules. Nat Chem Biol. 2006; 2(11): 618-26.

PubMed Abstract | Publisher Full Text

54. Park JE, Soung NK, Johmura Y, et al:: Polo-box domain: a versatile mediator of polo-like kinase function. Cell Mol Life Sci. 2010; 67(12): 1957-70. PubMed Abstract | Publisher Full Text | Free Full Text

55. F Yun SM, Moulaei T, Lim D, et al:: Structural and functional analyses of minimal phosphopeptides targeting the polo-box domain of polo-like kinase 1. Nat Struct Mol Biol. 2009; 16(8): 876-82.

PubMed Abstract | Publisher Full Text | Free Full Text | F1000 Recommendation

56. Liu F, Park JE, Qian WJ, et al.: Serendipitous alkylation of a PIk1 ligand uncovers a new binding channel. Nat Chem Biol. 2011; 7(9): 595-601. PubMed Abstract | Publisher Full Text | Free Full Text

57. Liu F, Park JE, Qian WJ, et al.: Identification of high affinity polo-like kinase 1 (PIk1) polo-box domain binding peptides using oxime-based diversification ACS Chem Biol. 2012; 7(5): 805-10. PubMed Abstract | Publisher Full Text | Free Full Text

58. Liu F, Park JE, Qian WJ, et al.: Peptoid-Peptide hybrid ligands targeting the polo box domain of polo-like kinase 1. Chembiochem. 2012; 13(9): 1291-6. PubMed Abstract | Publisher Full Text | Free Full Text

59. Qian W, Park JE, Liu F, et al.: Effects on polo-like kinase 1 polo-box domain binding affinities of peptides incurred by structural variation at the phosphoamino acid position. Bioorg Med Chem. 2013; 21(14): 3996-4003. PubMed Abstract | Publisher Full Text | Free Full Text

60. Qian WJ, Park JE, Lim D, et al:: Mono-anionic phosphopeptides produced by unexpected histidine alkylation exhibit high Plk1 polo-box domain-binding affinities and enhanced antiproliferative effects in HeLa cells. Biopolymers. 2014; 102(6): 444-55.

PubMed Abstract | Publisher Full Text | Free Full Text

61. Murugan RN, Park JE, Lim D, et al.: Development of cyclic peptomer inhibitors targeting the polo-box domain of polo-like kinase 1. Bioorg Med Chem. 2013; 21(9): 2623-34

PubMed Abstract | Publisher Full Text

62. Qian WJ, Park JE, Grant R, et al.: Neighbor-directed histidine N ( $\tau$ )-alkylation: A route to imidazolium-containing phosphopeptide macrocycles. Biopolymers. 2015; 104(6): 663-73.

PubMed Abstract | Publisher Full Text | Free Full Text

63. Ahn M, Han YH, Park JE, et al:: A new class of peptidomimetics targeting the polo-box domain of Polo-like kinase 1. J Med Chem. 2015; 58(1): 294-304. PubMed Abstract | Publisher Full Text

64. F Reindl W, Yuan J, Krämer A, et al.: Inhibition of polo-like kinase 1 by blocking polo-box domain-dependent protein-protein interactions. Chem Biol. 2008; 15(5): 459-66.

PubMed Abstract | Publisher Full Text | F1000 Recommendation

65. Reindl W, Yuan J, Krämer A, et al:: A pan-specific inhibitor of the polo-box domains of polo-like kinases arrests cancer cells in mitosis. Chembiochem. 2009; 10(7): 1145-8.

PubMed Abstract | Publisher Full Text

66. F Watanabe N, Sekine T, Takagi M: Deficiency in chromosome congression by the inhibition of Plk1 polo box domain-dependent recognition. J Biol Chem. 2009; 284(4): 2344-53.

PubMed Abstract | Publisher Full Text | F1000 Recommendation

67. Chen Y, Zhang J, Li D, et al:: Identification of a novel Polo-like kinase 1 inhibitor that specifically blocks the functions of Polo-Box domain. Oncotarget. 2017 8(1): 1234-46.

PubMed Abstract | Publisher Full Text | Free Full Text

68. Normandin K, Lavallée JF, Futter M, et al.: Identification of Polo-like kinase 1 interaction inhibitors using a novel cell-based assay. Sci Rep. 2016; 5: 37581. PubMed Abstract | Publisher Full Text | Free Full Text

69. Shan $\mathrm{HM}$, Shi $Y$, Quan J: Identification of green tea catechins as potent inhibitors of the polo-box domain of polo-like kinase 1. ChemMedChem. 2015 10(1): 158-63.

PubMed Abstract | Publisher Full Text

70. Yin Z, Song Y, Rehse PH: Thymoquinone blocks pSer/pThr recognition by Plk1 Polo-box domain as a phosphate mimic. ACS Chem Biol. 2013; 8(2): 303-8. PubMed Abstract | Publisher Full Text

71. Lee KS, Idle JR: Pinning down the polo-box domain. Chem Biol. 2008; 15(5): 415-6.

PubMed Abstract | Publisher Full Text

72. Liao C, Park JE, Bang JK, et al.: Exploring Potential Binding Modes of Smal Drug-like Molecules to the Polo-Box Domain of Human Polo-like Kinase 1. ACS Med Chem Lett. 2010; 1(3): 110-4.

PubMed Abstract | Publisher Full Text | Free Full Text

73. Aldrich C, Bertozzi C, Georg Gl, et al.: The Ecstasy and Agony of Assay Interference Compounds. ACS Cent Sci. 2017; 3(3): 143-7. PubMed Abstract | Publisher Full Text | Free Full Text

74. Archambault V, Normandin K: Several inhibitors of the Plk1 Polo-Box Domain turn out to be non-specific protein alkylators. Cell Cycle. 2017; 1-5. PubMed Abstract | Publisher Full Text

75. Hymel D, Burke TR Jr: Phosphatase-Stable Phosphoamino Acid Mimetics That Enhance Binding Affinities with the Polo-Box Domain of Polo-like Kinase 1. ChemMedChem. 2017; 12(3): 202-6.

PubMed Abstract | Publisher Full Text | Free Full Text

76. Zhao XZ, Hymel D, Burke TR Jr: Application of oxime-diversification to optimize ligand interactions within a cryptic pocket of the polo-like kinase 1 polo-box domain. Bioorg Med Chem Lett. 2016; 26(20): 5009-12. PubMed Abstract | Publisher Full Text | Free Full Text

77. Zhao XZ, Hymel D, Burke TR Jr: Enhancing polo-like kinase 1 selectivity of polo-box domain-binding peptides. Bioorg Med Chem. 2017; pii: S09680896(17)30170-0.

PubMed Abstract | Publisher Full Text 


\section{Open Peer Review}

\section{Current Peer Review Status:}

\section{Editorial Note on the Review Process}

Faculty Reviews are review articles written by the prestigious Members of Faculty Opinions. The articles are commissioned and peer reviewed before publication to ensure that the final, published version is comprehensive and accessible. The reviewers who approved the final version are listed with their names and affiliations.

\section{The reviewers who approved this article are:}

\section{Version 1}

\section{Wei Dai}

New York University School of Medicine, New York, USA

Competing Interests: No competing interests were disclosed.

\section{Vincent Archambault}

Université de Montréal, Montréal, Canada

Competing Interests: No competing interests were disclosed.

\section{Taebo Sim}

Chemical Kinomics Research Center, Korea Institute of Science and Technology, Seoul, South Korea Competing Interests: No competing interests were disclosed.

\section{Xiaoqi Liu}

Department of Biochemistry, Purdue University, West Lafayette, IN, USA

Competing Interests: No competing interests were disclosed.

The benefits of publishing with F1000Research:

- Your article is published within days, with no editorial bias

- You can publish traditional articles, null/negative results, case reports, data notes and more

- The peer review process is transparent and collaborative

- Your article is indexed in PubMed after passing peer review

- Dedicated customer support at every stage

For pre-submission enquiries, contact research@f1000.com 